\title{
Kappa opioid receptors mediate where fear is expressed following extinction training
}

\author{
Sindy Cole, Rick Richardson, and Gavan P. McNally ${ }^{1}$ \\ School of Psychology, The University of New South Wales, Sydney 2052, Australia
}

\begin{abstract}
Six experiments used a within-subjects renewal design to examine the involvement of kappa opioid receptors (KORs) in regulating the expression and recovery of extinguished fear. Rats were trained to fear a tone conditioned stimulus (CS) via pairings with foot shock in a distinctive context $(A)$. This was followed by extinction training of the CS in a second context (B). Finally, all rats were tested for fear to the tone in the extinction context (ABB) and the training (ABA) or a novel $(A B C)$ context. Intracerebroventricular (ICV) infusion of the KOR antagonist nor-binaltorphimine dihydrochloride (nor-BNI) dose-dependently prevented $A B A$ renewal of fear, but had no effect on the expression of $A B C$ renewal, the expression of extinction, or the expression of nonextinguished fear. Conversely, pretest infusion of the KOR agonist U50,488 hydrochloride $(\mathrm{U} 50,488)$ selectively facilitated the expression of $A B A$ renewal and had no effect on the expression of extinction. Pretest infusion of nor-BNI had no effect on the expression of context-specific latent inhibition. Collectively, these results suggest that KORs gate the expression of fear following extinction training and may comprise a critical neuropeptide component of the circuitry underlying context-dependent expression of fear.
\end{abstract}

The neural mechanisms underlying extinction have received considerable attention, at least in part, because extinction forms the basis of exposure-based therapies of human anxiety disorders. In extinction, a previously trained conditioned stimulus (CS) is repeatedly presented in the absence of the aversive unconditioned stimulus (US). Although this training produces a decrement in the conditioned response (CR) elicited by the CS, there is considerable evidence that extinction does not erase the original fear memory, but instead actively inhibits fear. This evidence comes from studies that show the return of extinguished fear responses in the absence of further CS-US training. For example, extinguished fear can return following presentation of the US (i.e., reinstatement) or following a context shift between extinction and test (i.e., renewal). Bouton and Bolles (1979) demonstrated that rats trained in context A and then extinguished in context B showed little responding in the extinction context, but fear was renewed when tested in the original training context (i.e., ABA renewal). Renewal also occurs if test takes place in a novel context (i.e., AAB, ABC renewal) (Bouton and Bolles 1979; Bouton and Ricker 1994; Harris et al. 2000), demonstrating that the key factor mediating CR recovery is that test takes place in a context other than that used for extinction training.

A neural circuit comprising the hippocampus, amygdale, and medial prefrontal cortex (mPFC) is proposed to regulate the contextual control of extinction (for review, see Bouton et al. 2006; Ji and Maren 2007), however, the exact pathways and neuropharmacological mechanisms through which this circuit functions are poorly understood. One neuropharmacological candidate for involvement in the renewal of fear is the endogenous opioid system. Opioid receptors have a well-documented role in learning and memory processes, particularly in fear learning. For example, systemic administration of the nonselective opioid receptor antagonist naloxone facilitates the acquisition but impairs the extinction and overexpectation of learned fear (Fanselow and Bolles 1979; McNally and Westbrook 2003; McNally et al. 2004a). Moreover, post-training injections of naloxone have been

\footnotetext{
${ }^{1}$ Corresponding author.
}

E-mail g.mcnally@unsw.edu.au; fax 61-2-93853044.

Article is online at http://www.learnmem.org/cgi/doi/10.1101//m.2049511. shown to enhance retention of an avoidance task (Messing et al. 1979), and in infant rats pretest naloxone injections have been shown to alleviate infantile amnesia of a fear conditioning session (Weber et al. 2006). Although a number of studies have demonstrated a role for the $\mu$-opioid receptor (MOR) in such effects (e.g., Fanselow et al. 1991; McNally et al. 2004b), a few studies have suggested that the $\kappa$-opioid receptor (KOR) may also contribute to fear learning. For example, central administration of a KOR antagonist impairs the acquisition of fear as measured by freezing and fear-potentiated startle (Fanselow et al. 1991; Knoll et al. 2007) and intra-accumbal infusions of a KOR agonist enhance the associative blocking of fear (Iordanova et al. 2006). Furthermore, KORs are expressed throughout the neural circuit proposed to underlie renewal (McLean et al. 1987; Mansour et al. 1995) and have been shown to modulate excitatory transmission in these structures (Wagner et al. 1992; Sbrenna et al. 1999).

In these experiments we examined the involvement of KORs in context-dependent expression of extinction and renewal of fear. Rats were trained to fear a tone CS in a distinctive context (A), followed by extinction training of the tone in a second context (B). Finally all rats were tested for fear to the tone in the extinction context and the training or a novel context. Prior to test rats received intracerebroventricular (ICV) infusions of a selective KOR agonist or antagonist.

\section{Results}

\section{Experiment 1: Nor-BNI impairs the expression} of $A B A$ renewal

In this experiment we used a within-subjects design to examine the effect of central KOR antagonism on the expression of ABA renewal of extinguished fear. The design is shown in Table 1. Rats were conditioned to fear a tone in context A followed by extinction (E) in context B. No-extinction controls (NE) were placed in context B but did not receive any CS presentations. Rats received an ICV infusion consisting of $10 \mu \mathrm{g}$ of the KOR selective antagonist nor-BNI (NBNI) or saline (SAL) prior to being tested for fear to the tone in both contexts (A and B) in a counterbalanced order. 
Table 1. Experimental designs

\begin{tabular}{|c|c|c|c|c|c|c|c|}
\hline Experiment & Group & D1 & D2 & D3 & D4 & D5 & D6 \\
\hline Experiment 1 & $\begin{array}{l}\text { NBNI-E } \\
\text { SAL-E } \\
\text { NBNI-NE } \\
\text { SAL-NE }\end{array}$ & $\begin{array}{l}\text { A:CS+ } \\
\text { A:CS+ } \\
\text { A:CS+ } \\
\text { A:CS+ }\end{array}$ & $\begin{array}{l}\text { B:CS- } \\
\text { B:CS- } \\
\text { B: } \\
\text { B: }\end{array}$ & $\begin{array}{l}\downarrow \text { NBNI } \\
\downarrow \text { SAL } \\
\downarrow N B N I \\
\downarrow S A L\end{array}$ & $\begin{array}{l}\text { A/B:CS- } \\
\text { A/B:CS - } \\
\text { A/B:CS - } \\
\text { A/B:CS - }\end{array}$ & $\begin{array}{l}\text { A/B:CS- } \\
A / B: C S- \\
A / B: C S- \\
A / B: C S-\end{array}$ & \\
\hline Experiment 2 & $\begin{array}{l}\text { NBNI } \\
\text { SAL }\end{array}$ & $\begin{array}{l}\mathrm{A}: \mathrm{CS}+ \\
\mathrm{A}: \mathrm{CS}+\end{array}$ & $\begin{array}{l}\mathrm{B}: \mathrm{CS}- \\
\mathrm{B}: \mathrm{CS}-\end{array}$ & $\begin{array}{l}\downarrow N B N I \\
\downarrow S A L\end{array}$ & $\begin{array}{l}\mathrm{B} / \mathrm{C}: \mathrm{CS}_{-} \\
\mathrm{B} / \mathrm{C}: \mathrm{CS}-\end{array}$ & $\begin{array}{l}\mathrm{B} / \mathrm{C}: \mathrm{CS}- \\
\mathrm{B} / \mathrm{C}: \mathrm{CS}-\end{array}$ & \\
\hline Experiment 3 & $\begin{array}{l}10 \mu \mathrm{g} \\
1 \mu \mathrm{g} \\
0 \mu \mathrm{g}\end{array}$ & $\begin{array}{l}\text { A:CS+ } \\
\text { A:CS+ } \\
\text { A:CS+ }\end{array}$ & $\begin{array}{l}\mathrm{B}: \mathrm{CS}- \\
\mathrm{B}: \mathrm{CS}- \\
\mathrm{B}: \mathrm{CS}-\end{array}$ & $\begin{array}{l}\downarrow N B N I \\
\downarrow N B N I \\
\downarrow S A L\end{array}$ & $\begin{array}{l}\text { A/B:CS - } \\
\text { A/B:CS- } \\
\text { A/B:CS- }\end{array}$ & $\begin{array}{l}\text { A/B:CS- } \\
\text { A/B:CS- } \\
\text { A/B:CS- }\end{array}$ & \\
\hline Experiment 4 & $\begin{array}{l}\text { NBNI } \\
\text { SAL }\end{array}$ & $\begin{array}{l}\mathrm{A}: \mathrm{CS}+ \\
\mathrm{A}: \mathrm{CS}+\end{array}$ & $\begin{array}{l}\mathrm{B}: \mathrm{CS}- \\
\mathrm{B}: \mathrm{CS}-\end{array}$ & $\begin{array}{l}\downarrow N B N I \\
\downarrow S A L\end{array}$ & $\begin{array}{l}\mathrm{B}: \mathrm{CS}- \\
\mathrm{B}: \mathrm{CS}-\end{array}$ & & \\
\hline Experiment 5 & $\begin{array}{l}\text { U50 } \\
\text { SAL }\end{array}$ & $\begin{array}{l}\mathrm{A}: \mathrm{CS}+ \\
\mathrm{A}: \mathrm{CS}+\end{array}$ & $\begin{array}{l}\mathrm{B}: \mathrm{CS}- \\
\mathrm{B}: \mathrm{CS}-\end{array}$ & $\begin{array}{l}\downarrow U 50 \\
\text { A/B:CS- } \\
\downarrow \text { SAL } \\
\text { A/B:CS - }\end{array}$ & $\begin{array}{l}\downarrow \cup 50 \\
\text { A/B:CS - } \\
\downarrow \text { SAL } \\
\text { A/B:CS - }\end{array}$ & & \\
\hline Experiment 6 & $\begin{array}{l}\text { NBNI } \\
\text { SAL }\end{array}$ & $\begin{array}{l}\mathrm{A}: C S- \\
\mathrm{A}: C S-\end{array}$ & $\begin{array}{l}\mathrm{A}: \mathrm{CS}- \\
\mathrm{A}: \mathrm{CS}-\end{array}$ & $\begin{array}{l}\mathrm{B}: \mathrm{CS}+ \\
\mathrm{B}: \mathrm{CS}+\end{array}$ & $\begin{array}{l}\downarrow N B N I \\
\downarrow S A L\end{array}$ & $\begin{array}{l}\mathrm{A} / \mathrm{B}: C S- \\
\mathrm{A} / \mathrm{B}: \mathrm{CS}-\end{array}$ & $\begin{array}{l}\text { A/B:CS- } \\
\text { A/B:CS- }\end{array}$ \\
\hline
\end{tabular}

Note: A, B, and C indicate the experimental context; CS+ denotes tone-foot-shock pairings; CS - denotes tone-alone presentations; $\downarrow$ denotes an ICV infusion; NBNI, SAL, or U50 refer to the drug administered (nor-BNI, saline, or U50,488, respectively); 10,1 , and $0 \mu \mathrm{g}$ refer to the dose of nor-BNI infused; nor-BNI was infused $24 \mathrm{~h}$ prior to the beginning of test due to the slow onset latency of the drug.

Two rats were excluded from the primary analysis as a result of misplaced cannulas resulting in group sizes as follows: NBNI-E $n=8$, NBNI-NE $n=7$, SAL-E $n=7$, and SAL-NE $n=8$. Pre-CS freezing for all experiments is shown in Table 2. Performance during extinction is displayed in Figure 1A. There were no differences in levels of pre-CS freezing $\left(F \mathrm{~s}_{(1,26)}<2.9, P \mathrm{~s}>0.05\right)$. A group (NBNI-E, SAL-E) by extinction block ANOVA on the extinction data yielded a significant linear trend of block $\left(F_{(1,13)}=108.35\right.$, $P<0.0001)$, because freezing levels decreased across extinction blocks. There was no significant effect of group $\left(F_{(1,13)}<1, P>\right.$ $0.05)$, and no group by extinction block interaction $\left(F_{(1,13)}<1\right.$, $P>0.05)$, indicating that there was no difference between groups in rates of extinction or overall levels of fear. Test performance is shown in Figure 1B. There were no differences in levels of pre-CS freezing in context $\mathrm{B}\left(F \mathrm{~s}_{(1,26)}<3.9, P \mathrm{~s}>0.05\right)$. For pre-CS freezing in context $A$, there were no significant effects of drug $\left(F \mathrm{~s}_{(1,26)}<1.2, P \mathrm{~S}>0.05\right)$, but extinction groups showed significantly less pre-CS freezing than no-extinction groups $\left(F_{(1,26)}=\right.$ $12.83, P=0.001)$. This is unsurprising given the no-extinction groups were conditioned in context $A$ and received no subsequent extinction training. Data from test were analyzed by means of planned analyses of variance preserving the $2(\mathrm{E}, \mathrm{NE}) \times 2(\mathrm{NBNI}$, $\mathrm{SAL}) \times 2$ (context: A, B) factorial design. There was an overall significant difference in levels of freezing between extinction and no-extinction groups $\left(F_{(1,26)}=31.28, P<0.0001\right)$. There was overall significantly more freezing in context A than in context $\mathrm{B}\left(F_{(1,26)}=95.16, P<0.0001\right)$ confirming the presence of within-subjects $\mathrm{ABA}$ renewal. There was a significant two-way interaction between context and extinction $\left(F_{(1,26)}=9.32, P=\right.$ 0.005 ) indicating that the differences in freezing between extinction and no-extinction groups were significantly greater in context $\mathrm{B}$ than in context $\mathrm{A}$. There was a significant two-way interaction between context and drug $\left(F_{(1,26)}=9.59, P=0.005\right)$ indicating that the difference in responding between groups receiving nor-BNI and saline was significantly greater in context A than in context B. Finally, there was a significant three-way interaction between extinction type, drug, and test context, which shows the reduction of freezing in context A in nor-BNI animals was specific to those receiving extinction training $\left(F_{(1,26)}<\right.$ $10.84, P=0.005)$. Further analyses confirmed the attenuation of tioning in context A followed by extinction in context B. Rats received an ICV infusion of either nor-BNI (NBNI) or saline (SAL) prior to being tested in both the extinction context $\mathrm{B}$ and a novel context $\mathrm{C}$ in a counterbalanced order.

One rat was excluded from the primary analysis as a result of a misplaced cannula resulting in group sizes as follows: NBNI $n=8$, SAL $n=6$. Performance during extinction is displayed in Figure 2A. There were no differences in levels of pre-CS freezing $\left(F_{(1,12)}<1, P>0.05\right)$. A group (NBNI, SAL) by extinction block ANOVA of the extinction data yielded a significant linear trend of block $\left(F_{(1,12)}=152.52, P<0.0001\right)$, because freezing levels decreased across extinction blocks. There were no significant differences between groups $\left(F_{\mathrm{s}_{(1,12)}}<2.9, \quad P \mathrm{~s}>0.05\right)$ indicating

Table 2. Mean (SEM) percent pre-CS freezing

\begin{tabular}{lllll}
\hline Experiment & \multicolumn{5}{c}{ Group } \\
\hline Experiment 1 & NBNI-E & SAL-E & NBNI-NE & SAL-NE \\
Extinction & $5(2)$ & $1(1)$ & $4(2)$ & $2(1)$ \\
Test B & $2(1)$ & $2(1)$ & $2(1)$ & $10(5)$ \\
Test A & $7(2)$ & $13(3)$ & $25(4)$ & $25(6)$ \\
Experiment 2 & NBNI & SAL & & \\
Extinction & $1(1)$ & $1(0)$ & & \\
Test B & $3(1)$ & $1(0)$ & & \\
Test C & $0(0)$ & $0(0)$ & & \\
Experiment 3 & $10 \mu \mathrm{g}$ & $1 \mu \mathrm{g}$ & $0 \mu \mathrm{g}$ & \\
Extinction & $2(2)$ & $1(0)$ & $4(1)$ & \\
Test B & $1(1)$ & $1(0)$ & $1(1)$ & \\
Test A & $11(4)$ & $16(6)$ & $17(2)$ & \\
Experiment 4 & $\mathrm{NBNI}$ & SAL & & \\
Extinction & $2(1)$ & $6(3)$ & & \\
Test B & $3(1)$ & $4(2)$ & & \\
Experiment 5 & $\mathrm{U} 50$ & SAL & & \\
Extinction & $3(1)$ & $1(0)$ & & \\
Test B & $2(1)$ & $7(3)$ & & \\
Test A & $24(5)$ & $21(7)$ & & \\
Experiment 6 & $\mathrm{NBNI}$ & SAL & & \\
Conditioning & $0(0)$ & $1(1)$ & & \\
Test A & $3(1)$ & $1(0)$ & & \\
Test B & $26(5)$ & $33(5)$ & & \\
\hline
\end{tabular}



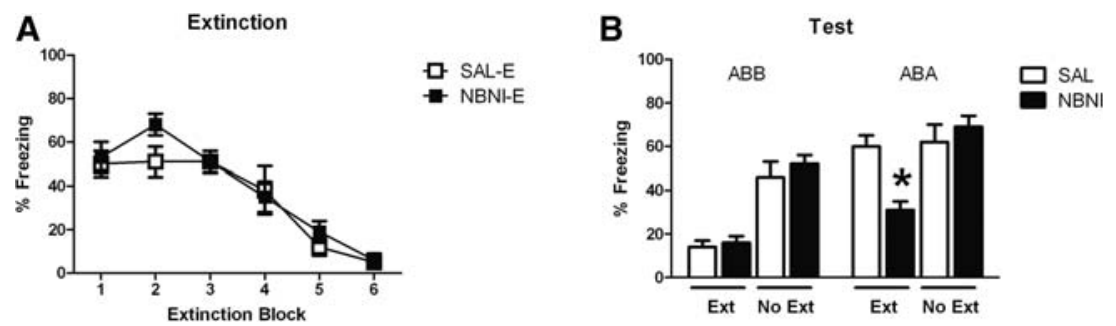

Figure 1. Nor-BNI impairs the expression of $A B A$ renewal. $(A)$ Mean ( $\pm S E M)$ freezing to the $C S$ across extinction blocks. $(B)$ Mean ( \pm SEM) freezing to the CS on test in the original conditioning context $A$ and the extinction context B. SAL-E animals showed within-subjects renewal, responding in A was greater than responding in $\mathrm{B}$. This renewal was prevented in NBNI-E rats, which showed less freezing in A. Nor-BNI infusion had no effect on freezing in NBNI-NE rats. *Represents significant difference in freezing in context A relative to group SAL-E $(P=0.001)$.

that there was no difference between groups in rates of extinction or overall levels of fear. Test performance is shown in Figure 2B. There were no differences in levels of pre-CS freezing in either context $\left(F \mathrm{~s}_{(1,12)}<2.8, P \mathrm{~s}>0.05\right)$. There was overall significantly more freezing in context $\mathrm{C}$ than context $\mathrm{B}\left(F_{(1,12)}=24.26, P<\right.$ $0.001)$ confirming the presence of $\mathrm{ABC}$ renewal. There was no significant effect of group $\left(F_{(1,12)}<1, P>0.05\right)$ and no significant group by test context interaction $\left(F_{(1,12)}<1, P>0.05\right)$, indicating that nor-BNI had no effect on the expression of $\mathrm{ABC}$ renewal.

\section{Experiment 3: The impairment of $A B A$ renewal by nor-BNI is dose-dependent}

The aim of Experiment 3 was to characterize the dose-response properties of nor-BNI on the expression of $\mathrm{ABA}$ renewal. The experiment used a $3(10,1,0 \mu \mathrm{g}) \times 2$ (context: A, B) design shown in Table 1 . All animals received conditioning in context A followed by extinction in context $\mathrm{B}$. Rats received an ICV infusion of nor-BNI (10 or $1 \mu \mathrm{g}$ ) or saline $(0 \mu \mathrm{g})$ prior to being tested in both contexts (A and B) in a counterbalanced order.

Two rats were excluded from the primary analysis as a result of misplaced cannulas resulting in group sizes as follows: $10 \mu \mathrm{g}$ $n=7,1 \mu \mathrm{g} n=7,0 \mu \mathrm{g} n=6$. Performance during extinction is displayed in Figure 3A. There were no differences in levels of pre-CS freezing $\left(F \mathrm{~s}_{(1,17)}<1.9, P \mathrm{~s}>0.05\right)$. A group $(10,1,0 \mu \mathrm{g})$ by extinction block ANOVA of the extinction data yielded a significant linear trend of block $\left(F_{(1,17)}=105.53, P<0.0001\right)$, because freezing levels decreased across extinction blocks. There were no significant differences between groups $\left(F \mathrm{~s}_{(1,17)}<2.0\right.$, $P$ s $>0.05)$ indicating that there was no difference between groups in rate of extinction or overall levels of fear. Test performance is shown in Figure 3B. There were no differences in levels of pre-CS freezing in either context $\left(F_{(1,17)}<1, P \mathrm{~s}>0.05\right)$. There was overall significantly more freezing in context $\mathrm{A}$ than in context $\mathrm{B}\left(F_{(1,17)}=56.04, P<0.0001\right)$ confirming the presence of ABA renewal. There was an overall effect of drug so that group $10 \mu \mathrm{g}$ showed significantly less freezing than groups 1 and $0 \mu \mathrm{g}$ $\left(F_{(1,17)}=4.59, P<0.05\right)$, which did not differ from each other $\left(F_{(1,17)}<1, P>\right.$ 0.05). Follow-up tests confirmed that nor-BNI dose-dependently impaired ABA renewal. There were no differences between groups in context $\mathrm{B}\left(\mathrm{Fs}_{(1,17)}<1.5\right.$, $P s>0.05)$. However, in context A, group $10 \mu \mathrm{g}$ showed significantly less freezing than groups 1 and $0 \mu \mathrm{g}\left(F_{(1,17)}=5.14\right.$, $P<0.05)$ and there was no difference
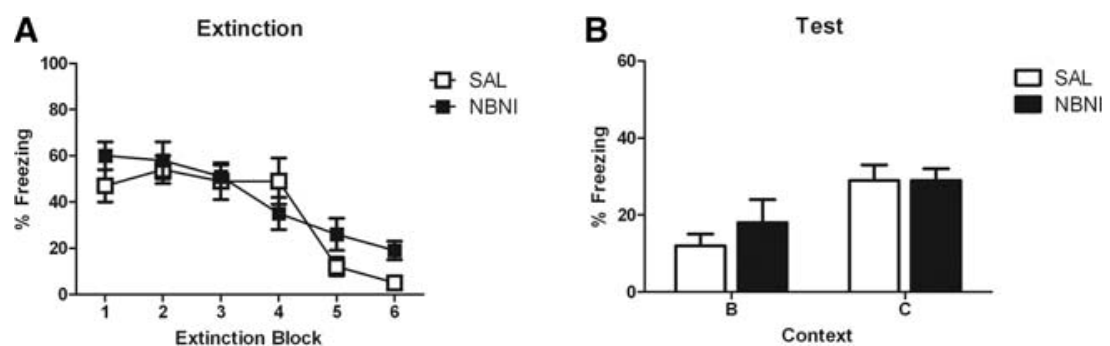

Figure 2. Nor-BNI has no effect on the expression of $A B C$ renewal. $(A)$ Mean ( \pm SEM) freezing to the $C S$ across extinction blocks. $(B)$ Mean $( \pm$ SEM) freezing to the $C S$ on test in the extinction context $B$ and a novel context $C$. Rats receiving saline prior to test showed $A B C$ renewal, responding in $C$ was greater than responding in B. Infusion of nor-BNI had no effect on the expression of this $A B C$ renewal. 
A

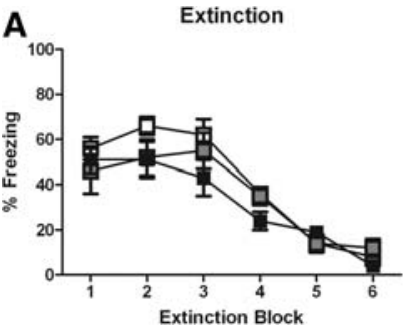

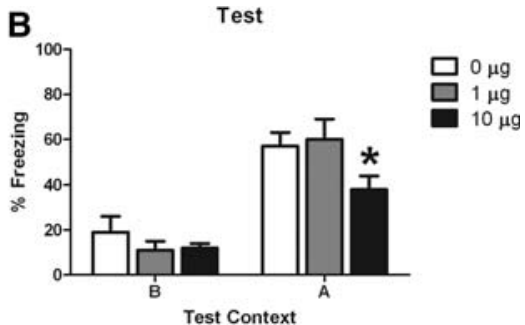

Figure 3. The impairment of $\mathrm{ABA}$ renewal by nor-BNI is dose-dependent. $(A)$ Mean $( \pm \mathrm{SEM})$ freezing to the $C S$ across extinction blocks. $(B)$ Mean $( \pm S E M)$ freezing to the CS on test in the original conditioning context $A$ and the extinction context $B$. Rats receiving 1 or $0 \mu \mathrm{g}$ of nor-BNI prior to test showed renewal, responding in $A$ was greater than responding in $B$. This renewal was prevented in rats receiving $10 \mu \mathrm{g}$ of nor-BNI, which showed less freezing in A. * Represents significant difference in freezing in context A relative to groups 1 and $0 \mu \mathrm{g}(P<0.05)$.

fear by selectively reducing freezing in the training context, context A. If KORs are critical for regulating the context-dependent expression of fear after extinction training then ICV infusions of a KOR agonist should selectively augment ABA renewal. We examined this possibility by testing the effect of a KOR agonist on expression of extinction and ABA renewal. Animals received training, extinction, and test as in Experiment 1. However, prior to each test rats received an ICV infusion of either the KOR agonist U50,488 (U50: $n=12$ ) or saline (SAL: $n=11$ ).

Performance during extinction is displayed in Figure 5A. There was no difference between groups in pre-CS freezing $\left(F_{(1,21)}<1.2, P>0.05\right)$. A group (U50, SAL) by extinction block ANOVA of the extinction data yielded a significant linear trend of block $\left(F_{(1,21)}=117.65, P<0.0001\right)$, because freezing levels decreased across extinction blocks. There was no significant effect of group $\left(F_{(1,21)}<1, P>0.05\right)$, and no group by extinction trial interaction $\left(F_{(1,21)}<1, P>0.05\right)$, indicating that there was no difference between groups in rate of extinction or overall levels of fear. Test performance is shown in Figure 5B. There was no difference in pre-CS freezing between groups in either test context $\left(F \mathrm{~s}_{(1,21)}<2.2, P \mathrm{~s}>0.05\right)$. Data from test were analyzed by means of planned analyses of variance preserving the $2(\mathrm{U} 50, \mathrm{SAL}) \times 2$ (context: A, B) factorial design. There was overall significantly more freezing in context A than context $\mathrm{B}\left(F_{(1,21)}=117.68, P<\right.$ $0.0001)$ confirming the presence of ABA renewal. There was a significant two-way interaction between context and group $\left(F_{(1,21)}=\right.$ $10.05, P<0.005)$ indicating that the difference in responding between groups U50 and SAL was significantly greater in context A than context B. Further analyses confirmed the enhancement of $\mathrm{ABA}$ renewal by U50,488. Infusion of U50,488 selectively enhanced $A B A$ renewal because group U50 showed significantly more freezing than group SAL in context A $\left(F_{(1,21)}=8.69, P<\right.$ $0.01)$, but these groups did not differ significantly in levels of freezing in context $\mathrm{B}\left(F_{(1,21)}<1, P>0.05\right)$.

\section{Experiment 6: Nor-BNI has no effect on the expression of context-specific latent inhibition}

The results of the previous experiments suggest that KORs are critical for the context-dependent expression of fear following extinction. This experiment was designed to examine if KORs act in a general manner to gate contextual control over fear expression or whether they act specifically to regulate the expression of extinguished fear. Latent inhibition, like extinction, results in nor-BNI prior to test had no effect on the expression of extinction.
A

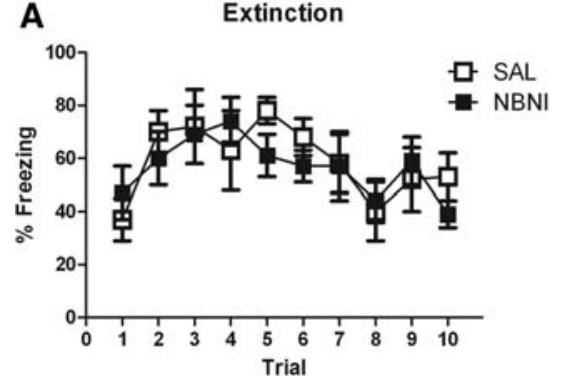
$\mathrm{CS}$ in context A, followed by a single conditioning session in the manner of the previous experiments, in context B. After an ICV infusion of either nor-BNI (NBNI, $n=7$ ) or saline (SAL, $n=$ 8 ) all rats were then tested for fear to the tone in both the preexposure (i.e., $\mathrm{ABA}$ ) and conditioning (i.e., $\mathrm{ABB}$ ) contexts.

Performance during conditioning is displayed in Figure 6A. There was no difference between groups in levels of pre-CS freezing $\left(F_{(1,13)}<2, P>0.05\right)$. A significant linear trend confirmed that fear accrued to the CS across conditioning $\left(F_{(1,13)}=106.25\right.$, $P<0.0001)$. There was no significant effect of group $\left(F_{(1,13)}<1\right.$, $P>0.05)$ and no significant group by conditioning trial interaction $\left(F_{(1,13)}<1, P>0.05\right)$ indicating that there was no difference between groups in rates of acquisition or overall levels of fear. Test performance is shown in Figure 6B. There was no significant difference in pre-CS freezing between groups in either test context $\left(F \mathrm{~s}_{(1,13)}<4.53, P \mathrm{~s}>0.05\right)$. Data from test were analyzed by means of planned analyses of variance preserving the $2(\mathrm{NBNI}, \mathrm{SAL}) \times 2$ (context: A, B) factorial design. There was overall significantly more freezing in the conditioning context $\mathrm{B}$ than the preexposure context A $\left(F_{(1,13)}=63.49, P<0.0001\right)$, confirming the presence of latent inhibition. There was no significant effect of group $\left(F_{(1,13)}<1, P>0.05\right)$ and no significant group by test context interaction $\left(F_{(1,13)}<1, \quad P>0.05\right)$, indicating that nor-BNI had no effect on the expression of context-specific latent inhibition.

\section{Discussion}

These experiments demonstrate a role for KORs in the ABA renewal of extinguished conditioned fear. Rats were trained to fear a tone CS via pairings with foot shock in a distinctive context (A), followed by extinction training of the CS in a second context (B). Finally all rats were tested for fear to the tone in both contexts (within-subjects ABA renewal). Control animals that received an
B Test

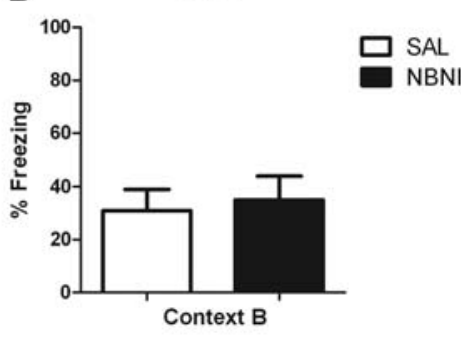

Figure 4. Nor-BNI has no effect on the expression of extinction. $(A)$ Mean $( \pm S E M)$ freezing to the CS across extinction trials. $(B)$ Mean $( \pm S E M)$ freezing to the CS in the extinction context $B$. Infusion of 
A

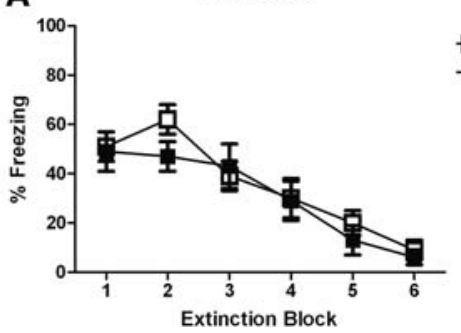

B

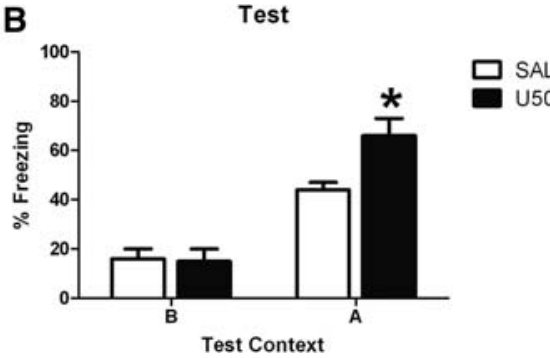

Figure 5. U50,488 enhances the expression of ABA renewal. $(A)$ Mean $( \pm S E M)$ freezing to the $C S$ across extinction blocks. $(B)$ Mean $( \pm S E M)$ freezing to the $C S$ on test in the original conditioning context $A$ and the extinction context $B$. Rats receiving saline prior to test showed renewal, responding in A was greater than responding in $B$. This renewal was enhanced in rats receiving the KOR agonist U50,488, which showed greater freezing in A. ${ }^{*}$ Represents significant difference in freezing in context A relative to group SAL $(P<0.01)$.

ICV infusion of saline prior to test demonstrated ABA renewal, showing greater freezing to the $\mathrm{CS}$ in the training context A than in the extinction context B. Central infusion of the KOR antagonist nor-BNI dose-dependently attenuated renewal by selectively reducing freezing in the training context (ABA) (Experiments 1 and 3). This effect of nor-BNI was specific to $\mathrm{ABA}$ renewal because nor-BNI had no effect on the expression of $A B C$ renewal (Experiment 2). Furthermore, nor-BNI had no effect on freezing in the extinction context (ABB) (Experiments 1-3). Pretest infusion of the KOR agonist U50,488 enhanced ABA renewal by selectively increasing freezing in the training context (ABA) and had no effect on freezing in the extinction context (ABB) (Experiment 5). The effects of nor-BNI were specific to modulating the context-dependent expression of fear following extinction, because pretest infusion of nor-BNI had no effect on the expression of freezing in the absence of extinction training (Experiment 1) and had no effect on the expression of contextspecific latent inhibition (Experiment 6). Taken together, these results suggest that the effects of nor-BNI were specific to affecting the expression of fear to a CS in the training context following extinction training.

Bouton $(1993,1994)$ proposed that animals use context to regulate memory retrieval of CSs that have a mixed history of reinforcement. For example, when rats receive CS-US pairings in context A followed by CS-alone presentations in context B, rats contextualize the second learning (extinction in context B) because this is when the CS becomes ambiguous. Retrieval of the extinction memory depends on the presence of the extinction context. When tested in the training context (ABA renewal) or a novel context (ABC renewal), the original CS-US memory is retrieved and fear is expressed. According to this account, only the CS-No US memory from extinction is context-dependent. However, Harris et al. (2000) established that the original CS-US memory from training is also contextualized and that this contextual modulation is only expressed after extinction training. Harris et al. trained rats with CSA-US pairings in context $\mathrm{A}$ and $\mathrm{CSB}$-US pairings in context $\mathrm{B}$, followed by extinction of both CSs in context C. Rats tested with CSA in context A showed significantly greater freezing than rats tested with CSA in context B. In other words, rats showed more fear to a CS when it was tested in the context where it had been paired with shock than when it
A Conditioning
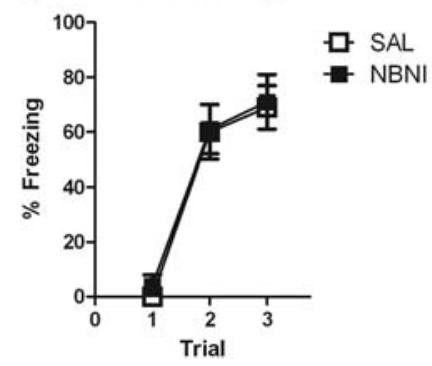

was presented in a context where a different CS had been paired with shock. Importantly, animals simply placed into context $\mathrm{C}$ without extinction training did not display this context specificity. In the present experiments, KOR manipulation only influenced responding when rats were tested in the training context $\mathrm{A}$ and only in animals that had undergone extinction. There was no effect of KOR antagonism on nonextinguished fear and no effect on fear renewed via testing in a novel context. These results parallel those of Harris et al. (2000). We suggest that KORs have a critical role in contextmediated retrieval of the CS-US memory following extinction. It is clear from inspection of Figure 1B that the attenuation of $\mathrm{ABA}$ renewal by nor-BNI was not complete. This suggests that the ABA renewal seen in saline animals consists of both a context-dependent retrieval of the CS-US memory and a contextindependent retrieval of the CS-US memory. Taken together, our findings suggest that nor-BNI acted to remove the contextdependent memory retrieval while leaving the context-independent memory retrieval unaffected. That the magnitude of the reduced $\mathrm{ABA}$ renewal in Experiment 1 was roughly the size of the $\mathrm{ABC}$ renewal seen in Experiment $2(\approx 30 \%)$ supports this suggestion.

This role for KORs in determining renewal of fear upon return to the training context complements the role of GABA in determining expression of fear upon return to the extinction context. For example, injections of the $\mathrm{GABA}_{\mathrm{A}}$ receptor inverse agonist FG7142 prevent the expression of fear extinction (Harris and Westbrook 1998). Injections of FG7142 have no effect on the expression of renewal or on the expression of latent inhibition (Harris and Westbrook 1998). Thus, after extinction training, $\mathrm{GABA}_{\mathrm{A}}$ receptors are important for regulating retrieval of the extinction memory in the extinction context, whereas KORs are important for regulating retrieval of the conditioning memory in the training context. The neuroanatomical locus for this role of KOR is unknown. Hippocampus is one possibility. There is some evidence that the hippocampus is important for renewal of fear because lesions or temporary inactivation of the dorsal hippocampus (DH) prevent renewal (Corcoran and Maren 2001, 2004; Ji and Maren 2005). In addition, Knapska and Maren (2009) reported that the CA1 and CA3 regions of the hippocampus are recruited during renewal. KORs are expressed at high

Figure 6. Nor-BNI has no effect on the expression of context-specific latent inhibition. $(A)$ Mean $( \pm S E M)$ freezing to the CS across conditioning trials. $(B)$ Mean $( \pm S E M)$ freezing to the $C S$ on test in the pre-exposure context $A$ and the conditioning context $B$. Rats receiving saline prior to test showed context-specific latent inhibition, responding in B was greater than responding in A. Infusion of nor-BNI had no effect on the expression of this latent inhibition.

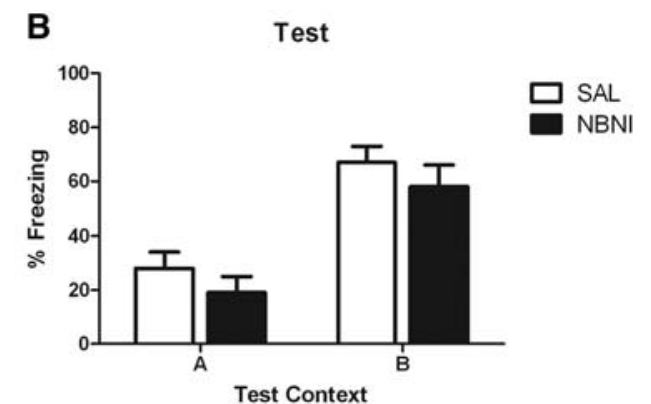


levels in the hippocampus and regulate excitatory amino-acid transmitter release, as well as synaptic plasticity there (for review, see Simmons and Chavkin 1996). Amygdala is another possibility. The amygdala basolateral nucleus (BLA) is critical for the acquisition and extinction of fear memories (for review, see Maren 2001; Walker and Davis 2002; Sotres-Bayon et al. 2004). Furthermore, electrophysiological studies have demonstrated that amygdala neurons encode conditional fear memories (for review, see Maren and Quirk 2004) and show context-dependent spike firing following extinction (Hobin et al. 2003). Further research is needed to examine whether KORs in these regions determine renewal of fear after return to the training context.

Nor-BNI and other KOR antagonists such as JDtic have been shown to produce anxiolytic-like effects in rodents (Knoll et al. 2007). It is therefore worth emphasizing that the attenuation of $\mathrm{ABA}$ renewal by nor-BNI in these experiments cannot be attributed to the anxiolytic properties of the drug or other nonspecific effects of nor-BNI on fear. There are at least four reasons why such accounts cannot explain the present pattern of results. First, nor-BNI infusion failed to reduce freezing in nonextinguished animals (Experiment 1). Second, nor-BNI selectively reduced freezing on test for renewal, leaving responding during test in the extinction context unaffected (Experiments 1, 3, and 4). Third, nor-BNI acted selectively to reduce freezing during test for $A B A$ renewal and did not affect freezing during test for $A B C$ renewal. Last, nor-BNI had no effect on the expression of latent inhibition (Experiment 6).

Finally, it is worth commenting on the implications of the present findings. Modulation of KORs has been shown to have pronounced effects on mood in both humans and rodents. For example in humans, activation of KORs via administration of a KOR agonist induces feelings of dysphoria (Pfeiffer et al. 1986). Similar treatment in rats produces depressive-like effects in animal models of depression such as the forced swim test and the intracranial self-stimulation test (Carlezon et al. 2006). This suggests that antagonizing KORs may have therapeutic value for the treatment of anxiety and depressive disorders. Indeed there is a growing body of literature suggesting that this is the case. For instance nor-BNI has been shown to act in an anti-depressant like manner by aiding recovery from a learned helplessness paradigm (Shirayama et al. 2004). Furthermore, as mentioned previously, nor-BNI has also been shown to possess anxiolytic properties (Knoll et al. 2007). These dual anxiolytic and anti-depressant properties of nor-BNI are of note considering standard antidepressants can induce anxiety in humans (Grillon et al. 2007). Extinction is a useful animal model for the exposure-based treatments used to treat anxiety disorders in humans. Moreover, relapse is a commonly occurring problem in the treatment of anxiety disorders (e.g., Rachman 1989). The finding that nor$\mathrm{BNI}$ acted selectively to attenuate renewal upon return to the context where that fear was acquired, but did not otherwise influence the expression of fear, suggests that KORs may be useful preclinical targets for relapse prevention.

In conclusion these experiments have shown that KORs regulate where fear is expressed following extinction training. The $\mathrm{ABA}$, but not $\mathrm{ABC}$, renewal of conditioned fear can be attenuated by the KOR antagonist nor-BNI and enhanced by the KOR agonist U50,488. Our results suggest that after extinction training KORs are important for regulating retrieval of the CS-US memory in the training context.

\section{Materials and Methods}

\section{Subjects}

Experimentally naive male Wistar rats (250-350 g) obtained from Monash Animal Services (Gippsland, Victoria, Australia) were housed in groups of eight in plastic cages with ad lib access to food and water. The colony room was maintained at $21^{\circ} \mathrm{C}$ on a $12 \mathrm{~h}$ light/dark cycle (lights on 7 a.m.). Rats were handled each day for $3 \mathrm{~d}$ to habituate to the experimenter. The procedures were approved by the Animal Care and Ethics Committee at the University of New South Wales, and conducted in accordance with the National Institute of Health Guide for the Care and Use of Laboratory Animals (Publication No. 80-23) revised 1996. The procedures were designed to minimize the number of animals used and their suffering.

\section{Surgery and histology}

Rats were injected intraperitoneally with $1.3 \mathrm{~mL} / \mathrm{kg}$ of the anesthetic ketamine (Ketapex, Apex Laboratories) at a concentration of $100 \mathrm{mg} / \mathrm{mL}$ and with $0.3 \mathrm{~mL} / \mathrm{kg}$ of the muscle relaxant xylazine (Rompun, Bayer) at a concentration of $20 \mathrm{mg} / \mathrm{mL}$. Each rat was placed in the stereotaxic apparatus (Model 900, Kopf), and the incisor bar was maintained at $3.3 \mathrm{~mm}$ below horizontal to achieve a flat skull position. A 26-gauge guide cannula (Plastics One) was targeted at the right lateral ventricle $(0.8 \mathrm{~mm}$ posterior, $1.5 \mathrm{~mm}$ lateral, and $4.0 \mathrm{~mm}$ ventral, relative to bregma). The guide cannula was fixed in position with dental cement and anchored by jeweler's screws. A dummy cannula was kept in the guide at all times except during microinjections.

Immediately after surgery, rats received intramuscular injections of $0.3 \mathrm{~mL}$ of a $300 \mathrm{mg} / \mathrm{mL}$ solution of procaine penicillin and $0.3 \mathrm{~mL}$ of $100 \mathrm{mg} / \mathrm{mL}$ cephazolin sodium, and subcutaneous injections of $5 \mathrm{mg} / \mathrm{kg}$ carprofen. Rats were allowed $5 \mathrm{~d}$ to recover from surgery, during which time they were handled and weighed daily. At the conclusion of each experiment rats were given an overdose of sodium pentobarbital and received a $50 \mu \mathrm{L}$ microinjection of cresyl violet into the right lateral ventricle. The brains were then removed and sectioned coronally through the location of the guide cannula. Correct cannula placement in the right lateral ventricle was confirmed by the presence of cresyl violet in both lateral ventricles, the ventral aspect of the third ventricle and the fourth ventricle.

\section{Infusions}

For intracranial infusions, the injection cannulas were connected to a $10 \mu \mathrm{L}$ glass Hamilton syringe mounted on an infusion pump. The microinjection cannula projected an additional $1 \mathrm{~mm}$ ventral to the tip of the guide cannula. Nor-BNI (Tocris) was dissolved in pyrogen-free saline to a concentration of $5 \mu \mathrm{g} / \mu \mathrm{L}$, except for Experiment 2 where an additional concentration of $0.5 \mu \mathrm{g} / \mu \mathrm{L}$ was used. U50,488 (Tocris) was dissolved in pyrogen-free saline to a concentration of $2.5 \mu \mathrm{g} / \mu \mathrm{L}$. Control infusions consisted of the pyrogen-free saline. All solutions were infused at volumes of $2 \mu \mathrm{L}$ over $2 \mathrm{~min}$ with the injection cannulas left in place for an additional $2 \mathrm{~min}$.

\section{Apparatus}

The present experiments were conducted in three sets of four chambers located within two different rooms in the laboratory which differed in their visual, olfactory, and tactile properties. The chambers that served as context A for Experiments 1-5 and context B for Experiment $6(30 \mathrm{~cm}$ [length] $\times 30 \mathrm{~cm}$ [width] $\times 30 \mathrm{~cm}$ [height]) were constructed entirely of clear Perspex and the floor in each chamber consisted of stainless steel rods $2 \mathrm{~mm}$ in diameter spaced $10 \mathrm{~mm}$ apart (center-to-center) that were wired to a constant-current shock generator. Each chamber was located in a sound attenuating chamber painted black and stood $2 \mathrm{~cm}$ above a tray of paper pellet bedding (Fibrecycle). Constant illumination was provided by a $15-\mathrm{W}$ house light. In the chambers that served as context B for Experiments $1-5$ and context A for Experiment $6(24 \mathrm{~cm}$ [length] $\times$ $30 \mathrm{~cm}$ [width] $\times 21 \mathrm{~cm}$ [height]) the top and rear walls, as well as the front hinged door and the floor, were constructed of clear Perspex and the side walls were made of stainless steel. Each chamber was located in a sound attenuating chamber painted 
white, illuminated with an infrared LED and stood $2 \mathrm{~cm}$ above a tray of paper pellet bedding (Fibrecycle). Diluted peppermint essence was placed in the bedding beneath the context B chambers. In the chambers that served as context $C$ in Experiment 2 ( $28 \mathrm{~cm}$ [length] $\times 40 \mathrm{~cm}$ [width] $\times 28 \mathrm{~cm}$ [height] $)$ the top was wire mesh and the floor, as well as the front and side walls, were constructed of opaque plastic. The rear wall was constructed of clear plastic. Each chamber was located in a sound attenuating chamber painted black and was illuminated by a $15-\mathrm{W}$ house light. The floor and sides of each chamber were wiped with dilute rose essence. All chambers were equipped with a ventilation fan (providing constant background noise), a speaker and digital video camera connected to a digital multiplexer, and a DVD recorder in an adjacent laboratory to record each session. Between each use, the chambers were wiped down with water, and where appropriate, the bedding beneath the floor was changed and essence was replaced. In all experiments the CS was a 20-sec $82 \mathrm{~dB}$ (A Scale), 750-Hz tone (0.1-sec rise and fall). The foot-shock US was a $0.5-\mathrm{sec}, 0.7-\mathrm{mA}$ unscrambled AC $50-\mathrm{Hz}$ shock from a constant current generator delivered to the grid floor of each chamber. The stimuli used for conditioning were controlled by computer (LabView, National Instruments).

\section{Procedure}

\section{Experiment 1}

On Day 1 rats received fear conditioning in context A. After a 10 -min pre-CS period all rats received three CS-US pairings with a 3-min intertrial interval (ITI). On Day 2 all rats were placed in context B. After a 2-min pre-CS period rats in the extinction groups received 18-CS alone presentations with a 3-min ITI. Rats in the no-extinction groups remained in the chambers for an equal duration but received no stimuli. On Day 3 rats received infusions of nor-BNI or saline as per group allocation and were then returned to their home cage. Infusions were administered $24 \mathrm{~h}$ prior to the beginning of test due to studies suggesting that nor-BNI has a slow onset (Horan et al. 1992) and remains at high levels in the rats after ICV administration for weeks (Zhang et al. 2007). On Days 4 and 5 all rats were tested for fear reactions to the CS in both context A and context B in a counterbalanced order. On test days rats were placed in the appropriate chamber where after a 2-min pre-CS period they received four presentations of the CS with a 2-min ITI.

\section{Experiment 2}

All animals received conditioning, extinction, and infusions as described for the extinction groups in Experiment 1. On Days 4 and 5 all rats were tested for fear reactions to the CS in both context $\mathrm{B}$ and context $\mathrm{C}$ in a counterbalanced order. On test days rats were placed in the appropriate chamber where after a 2-min pre-CS period they received four presentations of the CS with a 2-min ITI.

\section{Experiment 3}

All animals received conditioning, extinction, infusions, and test as described for the extinction groups in Experiment 1.

\section{Experiment 4}

Conditioning on Day 1 was identical to Experiment 1 . On Day 2 all rats received reduced extinction training in context $B$ which consisted of 10 CS-alone presentations with a 3-min ITI. On Day 3 rats received infusions as described above of either nor-BNI or saline. On Day 4 all rats were tested to for fear reactions to the CS in Context B in the manner of Experiment 1.

\section{Experiment 5}

Conditioning and extinction were identical to the extinction groups in Experiment 1. On Days 3 and 4 rats were tested for fear reactions to the $\mathrm{CS}$ in both context $\mathrm{A}$ and context $\mathrm{B}$ in a counterbalanced order as in Experiment 1. On each day rats received infusions of U50,488 or saline immediately prior to being placed in the conditioning chamber.

\section{Experiment 6}

On Days 1 and 2 all rats received pre-exposure to the CS in context A. On each day after a 2 -min pre-CS period they received 18 CS presentations with a 90-sec ITI. On Day 3 all rats received conditioning in context $\mathrm{B}$ as in Experiment 1. On Day 4 rats received infusions of nor-BNI or saline. On Days 5 and 6 rats were tested as in Experiment 1.

\section{Statistics}

Performance during conditioning, extinction, and test was recorded. The behavior was subsequently scored every 2 sec as either freezing (defined as the absence of all movement other than that required for breathing) or not freezing. The numbers of observations scored as freezing were summed and converted to a percentage. The data were analyzed by means of a planned orthogonal contrast testing procedure, and the Type I error rate was controlled at 0.05 for each contrast tested.

\section{Acknowledgments}

These experiments were supported by a grant from the Australian Research Council to G.P.M. and R.R. (DP0880854). We thank Fred Westbrook and Julia Langton for their helpful discussions of these experiments.

\section{References}

Bouton ME. 1993. Context, time, and memory retrieval in the interference paradigms of Pavlovian conditioning. Psychol Bull 114: 80-99.

Bouton ME. 1994. Conditioning, remembering, and forgetting. J Exp Psychol Anim Behav Process 20: 219-231.

Bouton ME, Bolles RC. 1979. Contextual control of the extinction of conditioned fear. Learn Motiv 10: 445-466.

Bouton ME, Ricker ST. 1994. Renewal of extinguished responding in a second context. Anim Learn Behav 22: 317-324.

Bouton ME, Westbrook RF, Corcoran KA, Maren S. 2006. Contextual and temporal modulation of extinction: Behavioral and biological mechanisms. Biol Psychiat 60: 352-360.

Carlezon WA Jr, Beguin C, DiNieri JA, Baumann MH, Richards MR, Todtenkopf MS, Rothman RB, Ma Z, Lee DY, Cohen BM. 2006. Depressive-like effects of the kappa-opioid receptor agonist salvinorin A on behaviour and neurochemistry in rats. J Pharmaco Exp Ther 316: $440-447$.

Corcoran KA, Maren S. 2001. Hippocampal inactivation disrupts contextual retrieval of fear memory after extinction. J Neurosci 21: 1720-1726.

Corcoran KA, Maren S. 2004. Factors regulating the effects of hippocampal inactivation on renewal of conditional fear after extinction. Learn Mem 11: 598-603.

Fanselow MS, Bolles RC. 1979. Naloxone and shock elicited freezing in the rat. J Comp Physiol Psych 93: 736-744.

Fanselow MS, Kim JJ, Young SL, Calcagnetti DC, DeCola JP, Helmstetter FJ, Landeira-Fernandez J. 1991. Differential effects of selective opioid peptide antagonists on the acquisition of Pavlovian fear conditioning. Peptides 12: $1033-1037$.

Grillon C, Levenson J, Pine DS. 2007. A single dose of the selective serotonin reuptake inhibitor citalopram exacerbates anxiety in humans: A fear-potentiated startle study. Neuropsychopharmacology 32: $225-231$.

Harris JA, Westbrook RF. 1998. Evidence that GABA transmission mediates context-specific extinction of learned fear. Psychopharmacology 140: $105-115$.

Harris JA, Jones ML, Bailey GK, Westbrook RF. 2000. Contextual control over conditioned responding in an extinction paradigm. J Exp Psychol Anim Behav Process 26: 174-185.

Hobin JA, Goosens KA, Maren S. 2003. Context-dependent neuronal activity in the lateral amygdala represents fear memories after extinction. J Neurosci 10: 8410-8416.

Horan P, Taylor J, Yamamura HI, Porreca F. 1992. Extremely long-lasting antagonistic actions of Nor-binaltorphimine 
(nor-BNI) in the mouse tail-flick test. J Pharmaco Exp Ther 260: $1237-1243$

Iordanova M, McNally GP, Westbrook RF. 2006. Opioid receptors in the nucleus accumbens regulate attentional learning in the blocking paradigm. J Neurosci 26: 4036-4045.

Ji J, Maren S. 2005. Electrolytic lesions of the dorsal hippocampus disrupt renewal of conditional fear after extinction. Learn Mem 12: $270-276$.

Ji J, Maren S. 2007. Hippocampal involvement in contextual modulation of fear extinction. Hippocampus 17: 749-758.

Knapska E, Maren S. 2009. Reciprocal patterns of c-Fos expression in the medial prefrontal cortex and amygdala after extinction and renewal of conditioned fear. Learn Mem 16: 486-493.

Knoll AT, Meloni EG, Thomas JB, Carroll FI, Carlezon WA Jr. 2007. Anxiolytic-like effects of kappa-opioid receptor antagonists in models of unlearned and learned fear in rats. J Pharmacol Exp Ther 323: $838-845$.

Maren S. 2001. Neurobiology of Pavlovian fear conditioning. Annu Rev Neurosci 24: 897-931.

Maren S, Quirk GJ. 2004. Neuronal signalling of fear memory. Nat Rev Neurosci 5: 844-852.

Mansour A, Fox CA, Akil H, Watson SJ. 1995. Opioid-receptor mRNA expression in the rat CNS: Anatomical and functional implications. Trends Neurosci 18: 22-29.

McLean S, Rothman RB, Jacobson AE, Rice KC, Herkenham M. 1987. Distribution of opiate receptor subtypes and enkephalin and dynorphin immunoreactivity in the hippocampus of squirrel, guinea pig, rat and hamster. J Comp Neurol 255: 497-510.

McNally GP, Westbrook RF. 2003. Opioid receptors regulate the extinction of Pavlovian fear conditioning. Behav Neurosci 117: $1292-1301$.

McNally GP, Pigg M, Weidemann G. 2004a. Blocking, unblocking, and overexpectation of fear: Opioid receptors regulate Pavlovian association formation. Behav Neurosci 118: $111-120$.

McNally GP, Pigg M, Weidemann G. 2004b. Opioid receptors in the midbrain periaqueductal gray matter regulate the extinction of Pavlovian fear conditioning. J Neurosci 24: $6912-6919$.
Messing RB, Jensen RA, Martinez JL, Spiehler VR, Vasquez BJ, Soumireu-Mourat B, Liang KC, McGaugh JL. 1979. Naloxone enhancement of memory. Behav Neural Biol 27: 266-275.

Pfeiffer A, Brantl V, Herz A, Emrich HM. 1986. Psychotomimesis mediated by kappa opiate receptors. Science 233: 774-776.

Rachman S. 1989. The return of fear: Review and prospect. Clin Psychol Rev 9: $147-168$.

Sbrenna S, Marti M, Calo G, Guerrini R, Beani L, Bianchi C. 1999. L-glutamate and g-aminobutyric acid efflux from rat cerebrocortical synaptosomes: Modulation by к- and $\mu$-but not $\delta$ - and opioid receptor like-1 receptors. J Pharmacol Exp Ther 291: 1365-1371.

Shirayama Y, Ishida H, Iwata M, Hazama GI, Kawahara R, Duman RS. 2004. Stress increases dynorphin immunoreactivity in limbic brain regions and dynorphin antagonism produces antidepressant-like effects. $J$ Neurochem 90: $1258-1268$.

Simmons ML, Chavkin C. 1996. Endogenous opioid regulation of hippocampal function. Int Rev Neurobiol 39: 145-196.

Sotres-Bayon F, Bush DE, LeDoux JE. 2004. Emotional perseveration: An update on prefrontal-amygdala interactions in fear extinction. Learn Mem 11: 525-535.

Wagner JJ, Caudle RM, Chavkin C. 1992. к-Opioids decrease excitatory transmission in the dentate gyrus of the guinea pig hippocampus. $J$ Neurosci 12: 132-141.

Walker DL, Davis M. 2002. The role of amygdala glutamate receptors in fear learning, fear-potentiated startle and extinction. Pharmacol Biochem Behav 71: 379-392.

Weber M, McNally GP, Richardson R. 2006. Opioid receptors regulate retrieval of infant fear memories: Effects of naloxone on infantile amnesia. Behav Neurosci 120: 702-709.

Westbrook RF, Jones ML, Bailey GK, Harris JA. 2000. Contextual control over conditioned responding in a latent inhibition paradigm. J Exp Psychol Anim Behav Process 26: 157-173.

Zhang H, Shi Y-G, Woods JH, Watson SJ, Ko M-C. 2007. Central к-opioid receptor-mediated antidepressant-like effects of nor-Binaltorphimine: Behavioral and BDNF mRNA expression studies. Eur J Pharmacol 570: $89-96$.

Received October 23, 2010; accepted in revised form December 7, 2010. 


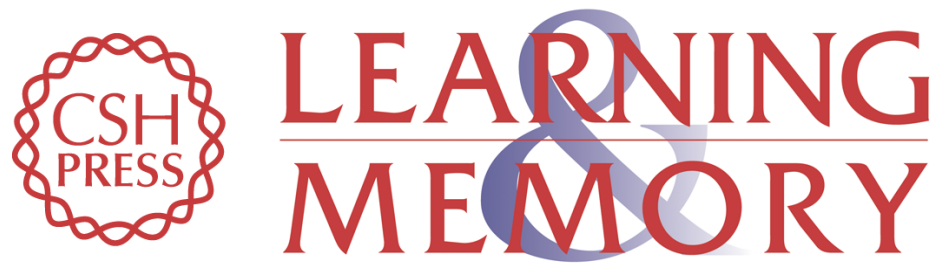

\section{Kappa opioid receptors mediate where fear is expressed following extinction training}

Sindy Cole, Rick Richardson and Gavan P. McNally

Learn. Mem. 2011, 18:

Access the most recent version at doi:10.1101//m.2049511

References This article cites 39 articles, 13 of which can be accessed free at:

http://learnmem.cshlp.org/content/18/2/88.full.htmI\#ref-list-1

License

Email Alerting Receive free email alerts when new articles cite this article - sign up in the box at the Service top right corner of the article or click here. 